\title{
Use of essential oils for the control of Varroa jacobsoni Oud. in honey bee colonies
}

\author{
Anton Imdorfa*, Stefan Bogdanova, Rubén Ibáñez Ochoa ${ }^{\mathrm{a}}$, \\ Nicholas W. Calderone ${ }^{b}$ \\ ${ }^{a}$ Forschungsanstalt für Milchwirtschaft, Sektion Bienen, Liebefeld, CH-3003 Bern, Switzerland \\ ${ }^{b}$ Department of Entomology, Comstock Hall, Cornell University, Ithaca, NY 14853, USA
}

(Received 3 September 1998; accepted 8 February 1999)

\begin{abstract}
Essential oils and essential oil components offer an attractive alternative to synthetic acaricides for the control of Varroa jacobsoni. They are generally inexpensive and most pose few health risks. Terpenes (mainly monoterpenes) are the main components of essential oils, comprising about $90 \%$ of the total. More than 150 essential oils and components of essential oils have been evaluated in laboratory screening tests. Very few of them, however, have proven successful when tested in field trials. Thymol and thymol blended with essential oils or essential oil components offer a promising exception. Mite mortality obtained with these formulations typically exceeds $90 \%$ and often approaches $100 \%$. In addition, residues in honey are low, even after long-term treatments. The exact conditions under which these formulations will yield reliable and effective control, however, have only been determined for certain European regions. Based on the available studies, relying solely on a single treatment with an essential oil or essential oil component is generally not sufficient to maintain mite populations below the economic injury level. Therefore, efforts are necessary to optimize the use of these substances and to incorporate them, along with other measures for limiting mite populations, into an integrated pest management strategy for control of Varroa jacobsoni. (c) Inra/DIB/AGIB/ Elsevier, Paris
\end{abstract}

Apis mellifera / Varroa jacobsoni / essential oil / screening / treatment / residue

\section{INTRODUCTION}

The association of Varroa jacobsoni Oudemans (Acari: Varroidae) with the western honey bee, Apis mellifera L., reportedly originated in the $1950 \mathrm{~s}[23,45,70,87]$ when the mites transferred to $A$. mellifera colonies that had been introduced into the home range of $A$. cerana, the mite's original host. $V$. jacobsoni has subsequently established a nearly world-wide distribution with respect to its new host $[36,70]$, with Australia being the only continent free of infestation.

\footnotetext{
* Correspondence and reprints

E-mail: anton.imdorf@fam.admin.ch
} 
$V$. jacobsoni and $A$. cerana maintain a stable relationship. However, mortality in colonies of A. mellifera in temperate regions approaches $100 \%[24,25]$. Colonies in temperate regions must be treated once or twice a year to maintain mite populations below economic injury levels. During the last 10 years, pyrethroids have been the primary source of insecticides used to control $V$. jacobsoni. Recently, mites in parts of Europe have developed resistance to two pyrethroids, fluvalinate and flumethrin $[4,21,27,30,32$, $63,66,74,75,89,92,96]$ and to coumaphos, an organophosphate [61]. Fluvalinate resistance has also been documented in the US [5]. The widespread use of synthetic lipophilic acaricides has lead to the accumulation of residues in beeswax, propolis and to a much lesser degree, in honey (see [9] for further references).

The development of acaricide resistance in $V$. jacobsoni populations and the spectre of the contamination of hive products provide considerable incentive to develop new treatment strategies that minimize the potential for the rapid development of resistance and the accumulation of residues. Since $V$. jacobsoni was introduced into Europe, intensive efforts have been made to develop alternative chemical control measures based on formic, lactic and oxalic acids, combined with biotechnical measures (see [48] for further references).

It is well known that many essential oils and their components exhibit acaricidal activity. Before $V$. jacobsoni was a worldwide pest, Angelloz [3] and Vecchi and Giordani [93] tested different components of essential oils for their activity against Acarapis woodi. Methyl salicylate and menthol proved to be toxic to the tracheal mite. In North America, where $A$. woodi has become an important bee parasite, menthol is widely used in control efforts (see [16] for further references). In this publication we review the research on the use of essential oils and several individual compounds found in essential oils as control measures for $V$. jacobsoni.

\section{PROPERTIES OF ESSENTIAL OILS}

'Essential oils' is the generic term for liquid, highly volatile plant compounds, characterized by an intensive, characteristic odor. They are present in almost all plant species, but only plants containing more than $0.1 \%$ oil can be called essential oils. Essential oils are plant products found in the flowers, fruits, seed, leaves, roots or wood and they can be present in all parts of a plant (e.g. Pinaceae) or only in specific parts (e.g. flowers of roses). Essential oils serve various functions in plants. They may act as attractants for insect pollinators; or, they can be repellent, providing protection against phytophagous insects. Many also exhibit fungicidal and bactericidal activity, protecting plants from microorganisms.

The essential oil composition of each plant species tends to be unique. However, some species have varieties, the so-called chemotypes, with variable essential oil compositions. Thyme (Thymus vulgaris), for example, has at least seven chemotypes. One group consists of the so-called 'strong chemotypes' that contain higher concentrations of the phenols thymol and carvacrol, while a second group, the 'mild chemotypes', includes varieties with higher amounts of alcohols such as geraniol, linalool and thujanol. The chemical composition of an essential oil often depends upon cultivation and climatic conditions. The specific extraction process used to produce an essential oil also influences its composition. Vapor distillation, cold pressing and chemical extractions produce oils of varying composition. The lack of constancy in the chemical composition of essential oils undoubtedly contributes to the variation in results obtained by different researchers (see section 4).

The main chemical groups of essential oils are the hydrocarbon terpenes and phenylpropanes. Terpenes, the main components, with about $90 \%$ of the total, are subdivided into monoterpenes $\left(\mathrm{C}_{10}\right)$, sesquiterpenes 
$\left(\mathrm{C}_{15}\right)$ and diterpenes $\left(\mathrm{C}_{20}\right)$. Monoterpenes, the main essential oil terpenes, are volatile and often appear with functional groups such as alcohols, phenols, aldehydes, ketones, esters and oxide derivatives. The essential oil components thymol, eucalyptol, camphor and menthol have a FAO GRAS status (generally recognized as safe) in concentrations of up to $50 \mathrm{mg} \cdot \mathrm{kg}^{-1}$. In pure form, however, these compounds, as well as many essential oils, can irritate eyes and mucous membranes and should be handled with care. Further details about essential oils can be found in extensive monographs on the subject $[1,37,38,79,95]$.

\section{SCREENING OF ESSENTIAL OILS}

In all, more than 150 essential oils and components of essential oils have been tested, but only the ones with a positive effect are mentioned in this section (for a complete list of all oils and chemical substances used see the references in tables $I-I I I)$.

\subsection{Mite and bee toxicity}

Hoppe [42] examined 55 essential oils for mite toxicity by evaporation and topi-

Table I. Toxicity of essential oils for V. jacobsoni and A. mellifera in percent [42].

\begin{tabular}{|c|c|c|c|c|c|c|c|c|}
\hline \multirow[t]{2}{*}{ Essential oil } & \multicolumn{3}{|c|}{ MM. evap (\%) } & \multicolumn{2}{|c|}{ MM top. (\%) } & \multicolumn{3}{|c|}{ BM evap. (\%) } \\
\hline & $24 \mathrm{~h}$ & $48 \mathrm{~h}$ & $72 \mathrm{~h}$ & $24 \mathrm{~h}$ & $48 \mathrm{~h}$ & $24 \mathrm{~h}$ & $48 \mathrm{~h}$ & $72 \mathrm{~h}$ \\
\hline Control & 0 & 1 & 11 & 0 & 4 & 0 & 1 & 1 \\
\hline Allylmustard & 100 & & & 95 & 100 & & & \\
\hline Anise & 5 & 80 & 100 & 55 & 60 & 0 & 2 & 5 \\
\hline Balm & 0 & 85 & 100 & 15 & 15 & 2 & 5 & 8 \\
\hline Caraway & 0 & 70 & 100 & 55 & 60 & 0 & 17 & 17 \\
\hline Cinnamon & 100 & & & 60 & 100 & 0 & 2 & 7 \\
\hline Clove & 100 & & & 100 & & 0 & 0 & 2 \\
\hline Coriander & 30 & 95 & 100 & 70 & 80 & 25 & 33 & 40 \\
\hline Dill & 0 & 60 & 95 & 25 & 30 & 2 & 17 & 32 \\
\hline Eucalyptus & 5 & 55 & 90 & 0 & 15 & 42 & 58 & 67 \\
\hline Fennel & 0 & 40 & 100 & 50 & 60 & 2 & 2 & 2 \\
\hline Garlic & 5 & 100 & & 85 & 85 & 100 & 100 & 100 \\
\hline Geranium & 5 & 55 & 95 & 70 & 70 & 0 & 2 & 2 \\
\hline Peppermint Jap. & 20 & 95 & 100 & 30 & 35 & 2 & 12 & 25 \\
\hline Lavender & 0 & 90 & 100 & 55 & 65 & 0 & 2 & 2 \\
\hline Marjoram & 15 & 35 & 100 & 5 & 5 & 5 & 13 & 15 \\
\hline Onion & 5 & 50 & 100 & 55 & 60 & 100 & 100 & 100 \\
\hline Orangeflowers & 5 & 70 & 100 & 45 & 45 & 2 & 15 & 18 \\
\hline Oregano & 0 & 90 & 100 & 80 & 90 & 3 & 43 & 87 \\
\hline Peppermint & 40 & 95 & 100 & 15 & 15 & 10 & 38 & 48 \\
\hline Rosemary & 10 & 45 & 100 & 15 & 15 & 2 & 3 & 3 \\
\hline Spearmint & 0 & 100 & & 55 & 55 & 2 & 15 & 17 \\
\hline Spik & 0 & 10 & 95 & 10 & 10 & & & \\
\hline Tansy & 15 & 75 & 100 & 15 & 25 & 7 & 17 & 17 \\
\hline Thyme & 0 & 85 & 100 & 80 & 80 & 62 & 78 & 92 \\
\hline Wintergreen & 50 & 100 & & 5 & 10 & 0 & 5 & 7 \\
\hline Wormwood & 0 & 25 & 100 & 15 & 15 & 7 & 63 & 95 \\
\hline
\end{tabular}

MM evap.: mite mortality by evaporation of essential oil; MM top.: mite mortality by topical application of essential oil; BM evap.: bee mortality by evaporation of essential oil. 
Table II. Effects of essential oils on behavior and reproduction of $V$. jacobsoni and on bee brood.

\begin{tabular}{|c|c|c|c|c|c|c|}
\hline \multirow[t]{2}{*}{ Essential oil } & \multicolumn{4}{|c|}{ Repellent-Attractant } & \multirow{2}{*}{$\frac{\text { Brood mortality }}{\begin{array}{c}\text { Bunsen } \\
{[12]}\end{array}}$} & \multirow{2}{*}{ 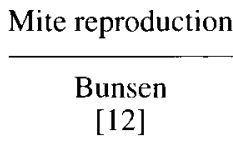 } \\
\hline & $\begin{array}{c}\text { Hoppe } \\
{[42]}\end{array}$ & $\begin{array}{c}\text { Kraus } \\
{[53]}\end{array}$ & $\begin{array}{c}\text { Bunsen } \\
\text { [12] }\end{array}$ & $\begin{array}{c}\text { Colin } \\
{[18]}\end{array}$ & & \\
\hline Anona & & & & $\mathrm{R}$ & & \\
\hline Balm & & $\mathrm{R}$ & & & $\mathrm{m}$ & \\
\hline Bergamot & & $\mathrm{R}$ & & & $\mathrm{h}$ & \\
\hline Caraway & & & $\mathrm{R}$ & & $\mathrm{s}$ & - \\
\hline Cardamom & & $\mathrm{R}$ & & & $s$ & \\
\hline Cedar & & - & $\mathrm{R}$ & & - & - \\
\hline Celery & & - & $\mathrm{R}$ & & $s$ & - \\
\hline Chamomille & & $\mathrm{R}$ & & & & \\
\hline Chenopodium & & & & $\mathrm{R}$ & & \\
\hline Cinnamon & A & A & & & $\mathrm{h}$ & - \\
\hline Citronella & & $\mathrm{R}$ & & & $\mathrm{s}$ & \\
\hline Clove & A & A & - & & $\mathrm{s}$ & $\mathrm{i}$ \\
\hline Coriander & & $\mathrm{R}$ & & & $s$ & \\
\hline Dwarf pine & & $\mathrm{R}$ & & & & \\
\hline Eucalyptus & $\mathrm{R}$ & $\mathrm{R}$ & & & $s$ & \\
\hline Fennel & - & $\mathrm{R}$ & & & $\mathrm{h}$ & \\
\hline Fir needle & & $\mathrm{R}$ & $\mathrm{R}$ & & $\mathrm{h}$ & - \\
\hline Galbanum & & & $\mathrm{R}$ & & $\mathrm{m}$ & - \\
\hline Geranium & & $\mathrm{R}$ & & & & \\
\hline Grapefruit & & $\mathrm{R}$ & & & & \\
\hline Juniper & & - & $\mathrm{R}$ & & $\mathrm{s}$ & - \\
\hline Laurel & & $\mathrm{R}$ & & & & \\
\hline Lavender & $\mathrm{R}$ & $\mathrm{R}$ & $\mathrm{R}$ & & $s$ & d \\
\hline Lemon & $\mathrm{R}$ & & - & & $\mathrm{m}$ & i \\
\hline Lily & & & - & & $\mathrm{s}$ & i \\
\hline Mandarin & & & $\mathrm{R}$ & & $\mathrm{s}$ & - \\
\hline Marjoram & & $\mathrm{R}$ & & & $\mathrm{s}$ & \\
\hline Melissa & $\mathrm{R}$ & & $\mathrm{R}$ & & $\mathrm{s}$ & - \\
\hline Mint & & $\mathbf{R}$ & & & & \\
\hline Neem & & & $\mathrm{R}$ & & & - \\
\hline Nerolidol & & & $\mathrm{R}$ & & $\mathrm{h}$ & - \\
\hline Nutmeg & & $\mathrm{R}$ & & & $\mathrm{s}$ & \\
\hline Peppermint & $\mathrm{R}$ & $\mathrm{R}$ & - & & $s$ & $\mathrm{i}$ \\
\hline Pine & & & $\mathrm{R}$ & & $\mathrm{s}$ & - \\
\hline Rose & & $\mathrm{R}$ & & & $\mathrm{m}$ & \\
\hline Rosemary & & $\mathrm{R}$ & & & l & \\
\hline Sage & & & $\mathrm{R}$ & $\mathrm{R}$ & 1 & - \\
\hline Sandal-wood & & $\mathrm{R}$ & & & & \\
\hline Savory & & & $\mathrm{R}$ & & $\mathrm{h}$ & - \\
\hline Thyme & $\mathbf{R}$ & & & $\mathrm{R}$ & $\mathrm{h}$ & - \\
\hline Valerian & & A & & & & \\
\hline Violet & & & $\mathrm{R}$ & & $\mathrm{s}$ & - \\
\hline Wine's yeast & & & $\mathrm{R}$ & & $\mathrm{m}$ & - \\
\hline Wintergreen & & A & A & & $\mathrm{s}$ & - \\
\hline Wormwood & $\mathrm{R}$ & & & & & \\
\hline
\end{tabular}

R: repellent; A: attractant; s: small; $m=$ medium; h: high; i: increase; d: decrease; -: neutral. Note that wintergreen oil is an essential oil with methyl salycilate as the main component, but it is also a common generic name for pure methyl salycilate. 
Table III. Effects of different components of essential oils and organic substances on behavior and reproduction of $V$. jacobsoni and on bee brood.

\begin{tabular}{|c|c|c|c|c|c|}
\hline \multirow{2}{*}{$\begin{array}{l}\text { Components of essentials } \\
\text { oils and other organic } \\
\text { substances* }\end{array}$} & \multicolumn{3}{|c|}{ Repellent-Attractant } & \multirow{2}{*}{ 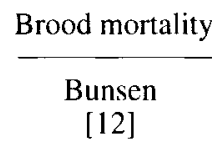 } & \multirow{2}{*}{ 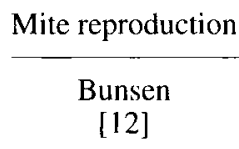 } \\
\hline & $\begin{array}{l}\text { Hoppe } \\
\text { [42] }\end{array}$ & $\begin{array}{c}\text { Kraus } \\
{[53]}\end{array}$ & $\begin{array}{c}\text { Bunsen } \\
\text { [12] }\end{array}$ & & \\
\hline Acethyl eugenol & & A & & & \\
\hline Anethole & & $\mathrm{R}$ & $\mathrm{R}$ & $\mathrm{h}$ & - \\
\hline Benzoic acid* & & $\mathrm{R}$ & & & \\
\hline Bornyl acetate* & & $\mathrm{R}$ & & & \\
\hline Camphor DL & & & - & $\mathrm{s}$ & $\mathrm{d}$ \\
\hline Caryophyllene & & & $\mathrm{R}$ & $\mathrm{m}$ & - \\
\hline Cinnamaldehyde & & A & & & \\
\hline Citral & & $\mathrm{R}$ & $\mathrm{R}$ & $\mathrm{m}$ & - \\
\hline Citronellal & & $\mathrm{R}$ & $\mathrm{R}$ & $s$ & - \\
\hline Citronellol & & $\mathrm{R}$ & - & $\mathrm{m}$ & $\mathrm{d}$ \\
\hline Coumarin* & & $\mathrm{A}$ & & & \\
\hline Decenal* & & & $\mathrm{R}$ & $\mathrm{m}$ & - \\
\hline Elemol & & $\mathrm{R}$ & & & \\
\hline Eucalpytol & & $\mathrm{R}$ & & & \\
\hline Eugenol & A & $\mathrm{A}$ & - & $\mathrm{m}$ & $\mathrm{i}$ \\
\hline Geraniol & & $\mathrm{R}$ & & & \\
\hline Isoeugenol & & $\mathrm{R}$ & & & \\
\hline Linalool & & - & - & $\mathrm{h}$ & d \\
\hline Linalyl acetate & & & $\mathrm{R}$ & $\mathrm{h}$ & $\mathrm{d}$ \\
\hline Menthol & & $\mathrm{R}$ & & & \\
\hline Menthone & & $\mathrm{A}$ & & & \\
\hline Nerolidol & & & $\mathrm{R}$ & & \\
\hline Octenal* & & & $\mathrm{R}$ & $\mathrm{h}$ & - \\
\hline Phenyl acetylene* & & & $\mathrm{R}$ & s & - \\
\hline Pinene & & $\mathrm{R}$ & - & s & d \\
\hline Terpineol & & & - & $\mathrm{h}$ & $\mathrm{d}$ \\
\hline
\end{tabular}

R: repellent; A: attractant; s: small; m: medium; h: high; i: increase; d: decrease; -: neutral (no effect).

cal application tests. In the evaporation test, a group of ten mites, fixed dorsally on a small glass plate and placed in a $37-\mathrm{mL}$ glass were exposed to $0.5 \mu \mathrm{L}$ of pure essential oil applied on a filter paper. For the topical application test, mites were fixed in the same way, and $0.2 \mu \mathrm{L}$ of a $5 \%$ solution of essential oil in aqueous acetone was applied to the ventral side of the mites. Toxicity to bees was evaluated by placing 20 bees in a small cage held in a closed $3.4-\mathrm{L}$ glass receptacle containing $10 \mu \mathrm{L}$ pure essential oil. The mortality of mites and bees was evaluated after 24,48 and $72 \mathrm{~h}$. After $72 \mathrm{~h}$, 24 essential oils produced a mite mortality of more than $90 \%$ (table I). After topical application, where the maximal effect was reached after $48 \mathrm{~h}$, only three oils produced the same level of mite mortality. This suggests that passive evaporation is the most appropriate form of application for the essential oils and their components. Of the 24 oils causing a high mite mortality, only nine resulted in bee mortality below $10 \%$. In another bee toxicity test in which $1 \mathrm{~mL}$ of a 
$0.5-20 \%$ essential oil solution in aqueous acetone was sprayed on caged bees, only elevated concentrations of wintergreen oil, which were well tolerated by bees, caused a high mite mortality. From 55 essential oils only wintergreen oil was chosen for field trials.

Kraus [53] investigated mite and bee mortality resulting from exposure to marjoram, cinnamon, clove, citronella and lavender oils. Ten bees, carrying one mite each, were kept under a beaker with a piece of wax foundation containing $0.1,1$ or $10 \%$ of an essential oil. After 3 days, both mite and bee mortality were determined. Clove oil at $1 \%$ concentration in wax caused mite mortality of more than $80 \%$ and a bee mortality equal to that in the untreated control, while at $10 \%$, both mite and bee mortality were close to $100 \%$. Application of $10 \%$ marjoram oil resulted in a mite mortality of $100 \%$ and bee mortality of $20 \%$, the latter not being significantly different from the control.

Bunsen [12] tested bee tolerance to lavender, melissa, wintergreen, fir needle, Pinus mugo ssp. mugo and neem oils and citral. In cages containing 20 bees, $300 \mu \mathrm{L}$ of 0.1 , 1 or $10 \%$ oil in acetone were evaporated from a filter paper. Bee behavior was observed for $7 \mathrm{~h}$. All concentrations of citral, but only the highest concentrations of lavender and melissa oils, disturbed bee behavior. The other oils showed no effects.

Colin et al. [19] sprayed water emulsions containing $1.25,2.5,5,10,20$ or $40 \mathrm{~g} \cdot \mathrm{L}^{-1}$ of thyme, sage, Chenopodium spp. and Anona spp. oils onto filter paper and placed them in a plastic petri dish containing ten mites. After $24 \mathrm{~h}$, emulsions containing $20 \mathrm{~g} \cdot \mathrm{L}^{-1}$ of thyme, sage and chenopodium oils which caused a mortality of more than $90 \%$ compared to less than $5 \%$ for the water control.

Sammataro et al. [83] exposed four to five mites to the vapors of $40 \mu \mathrm{L}$ of a $50 \%$ solution of essential oil dissolved in olive oil and applied to filter paper discs placed in a glass petri dish. Mite mortality was $100 \%$ with oregano oil, $87.2 \%$ with clove oil, $75.5 \%$ with bay oil and $59.4 \%$ with teatree oil.

Marchetti et al. [68] examined the effects of the application of smoke produced by burning material from ten different plants. Twenty smoke strokes from $4 \mathrm{~g}$ plant material were introduced into test hives. The entrance of the hives was closed for $60 \mathrm{~min}$. Mentha piperita was the most efficacious, detaching $75 \%$ more mites than obtained with control smoke from combusted sack jute. Eischen and Wilson [28, 29] treated small groups of approximately 250 infested bees with cool smoke from burning plant materials for $60 \mathrm{~s}$ and evaluated the mite fall over $24 \mathrm{~h}$. The smoke from Tanacetum vulgare, Juniperus virginiana, Citrus sp., Larrea tridentata, Melaleuca quinquenervia, Azadirachta indica, Oxalis rubra and Rhus typhina knocked down $70-90 \%$ of the mites.

Imdorf et al. [49] devised an assay in which the dose-response relationships between an airborne acaricide and corresponding mite and bee mortalities were examined for several volatile substances. For each test, two cages (Liebefeld type), each containing 100 bees and $20-40$ mites, were placed in a desiccator and exposed to air containing the vapor of specific volatile substances at specific concentrations. Different concentrations were produced by mixing fresh air with air containing the active ingredient. The test was performed in an incubator at a temperature of $32{ }^{\circ} \mathrm{C}$ and a relative humidity of $50-60 \%$. The concentration of the active ingredient in the desiccator was measured at 24,48 and $72 \mathrm{~h}$, and after $72 \mathrm{~h}$ the dead bees and the fallen mites were counted. Concentrations of $5-15 \mu \mathrm{g}$ of thymol, $50-150 \mu \mathrm{g}$ camphor and $20-60 \mu \mathrm{g}$ menthol per liter of air killed nearly $100 \%$ of the mites without a noticeable loss of bees. Eucalyptol at $240 \mu \mathrm{g} \cdot \mathrm{L}^{-1}$ caused $100 \%$ mite mortality, but also killed $25 \%$ of the bees. Imdorf et al. (unpublished data) tested other monoterpenes using the same assay and 
found that concentrations of 400-1 $000 \mu \mathrm{g}$ p-cymene, $120-260 \mu \mathrm{g} \alpha$-thuyon and $30-100 \mu \mathrm{g}$ isopinocamphon per litre of air caused mite mortality of nearly $100 \%$, but were well tolerated by bees. Isopinocamphon is the main component of ysop oil (isopinocamphon type). Mortality resulting from exposure to $\alpha$-terpinene was high for both mites and bees. Limonene and $\alpha$-pinene, even at high concentrations, produced little mortality of either mites or bees.

\subsection{Repellent, attractant and reproduction effects on $V$. jacobsoni and brood tolerability}

Different screening tests were used for studying repellent and attractant effects. Hoppe and Schley [44] placed a wax arena divided into four parts in a petri dish. One microliter of oil was applied at the edge of two of the four opposite fields. Ten mites were released in the middle of the arena and their locations were recorded every $2 \mathrm{~min}$. for $30 \mathrm{~min}$. Kraus [53] devised an assay consisting of two small wax tubes (length $=$ $3 \mathrm{~cm}$, diameter $=1 \mathrm{~cm}$, weight $=5 \mathrm{~g}$ ). The test substances were mixed in the wax of one of the tubes at concentrations of 0.1 , 0.5 or $1 \%$, the other tube being an untreated control. Five mites were placed in the two connecting tubes, their position was observed through the thin wax tube wall after 30 and $90 \mathrm{~min}$. Bunsen [12] developed a test where $10 \mu \mathrm{L}$ of a $1 \%$ emulsion of active ingredient in water were dropped on brood in cells just before operculation. A control treatment was conducted with $10 \mu \mathrm{L}$ water containing $1 \%$ emulsifier. The brood was frozen 18 days after egg laying, and the following variables were measured: brood mortality, repellent and attractant effects and effect on mite reproduction. Colin et al. [19] devised a choice test using a petri dish arena in which mites had a choice between a bee larva sprayed with an emulsion of $20 \mathrm{~g} \cdot \mathrm{L}^{-1}$ of active ingredient or water as a control. The distribution of mites between treated and control larvae was determined after 72 h. Tables $I I$ and $I I I$ summarize the results of those tests in which essential oils and different natural substances (most of them being components of essential oils) exerted an effect in any of the tests. A direct comparison of the repellent and the attractant effects in the different studies is not possible because the various tests were quite different. The effects are, however, mostly corroborative, e.g. lavender oil was repellent in all three tests where it was examined. Not all oils and organic substances showed effects in the different tests.

Kraus [53,54] developed other tests to evaluate the effects of essential oils on olfactory orientation by $V$. jacobsoni. Citronella, lavender and marjoram oils exhibited repellent effects, while cinnamon and clove oils were attractants. The capacity of $V$. jacobsoni to differentiate between drones and workers was not disturbed. The orientation of $V$. jacobsoni towards adult bees and its capacity to differentiate between nurse bees and pollen foragers was impeded. When brood comb wax of a mating hive contained $0.1 \%$ of the repellent marjoram oil, the brood infestation of $V$. jacobsoni was significantly diminished. This phenomenon was explained by a disturbance of $V$. jacobsoni brood recognition.

Bunsen [12] conducted field trials with oils from fir needles, Pinus mugo spp. mugo, lavender, melissa, wintergreen and with citral, all of which, with the exception of wintergreen, were repellent in the screening test (table II). One comb from a bee colony was sprayed with $20 \mathrm{~mL}$ acetone-oil solution $(9: 1 \mathrm{vol} / \mathrm{vol})$ and the same variables were examined as in the screening test above. Only the attractant effect of wintergreen oil was confirmed. This effect, however, decreased with increasing mite infestation rate. Unexpectedly, lavender oil, which was repellent in the laboratory test, exhibited an attractant effect in the field trial and caused a higher mite infestation rate of brood. Also, both Pinus mugo spp. mugo oil (without an effect in the screening test) and fir needle 
oil (repellent in screening test), significantly decreased mite reproduction. However, when all combs of a small mating hive were sprayed with the same oils, these effects could not be reproduced. The effectiveness of trapping combs treated with the attractive oils of lavender and wintergreen for reducing mite populations was no greater than that of the untreated controls.

Summarizing the results of all different tests, it can be concluded that the effects observed in the different tests are not consistent and that it is difficult to predict the varroacidal activity of essential oils in field conditions from their performance in laboratory assays. The behavior tests were aimed at developing a method to disturb olfactory orientation of $V$. jacobsoni. When the tests were carried out with small colonies, however, most oils and chemical substances were not efficient in reducing mite population. Only marjoram, sage, thyme and wintergreen oils turned out to have an acceptable level of activity against $V$. jacobsoni in bee colonies (see section 4 ).

\section{APPLICATION IN THE HIVE}

\subsection{Essential oils}

The first trials for the control of $V$. jacobsoni with essential oils in free flying colonies were conducted in Russia. Sidorov et al. [86] tested the effects of mint, pine-needle, aniseed, fennel, wormseed, dragons head, citralinic and Chenopodium oils. All tested oils had an unquantified activity against $V$.jacobsoni. Wormseed oil had a relatively low efficacy, while Chenopodium oil was very toxic for bees. Treatment of bee colonies caused excitation of bees.

Shutov [85] made a decoction out of a mixture of leafless Anabasis sp. (shoots), Calendula sp. (herbs), Tanacetum vulgare (flowers), Leonurus cardiaca (herbs), Matricaria recutita (herbs), Ephedra sp. (shoots), Quercus sp. (roots), Artemisia apsithicum (shoots, inflorescences) and Pinus sp. (buds with shoots). One colony group was fed $30-60 \mathrm{~mL}$ of a decoction-sugar solution, the other was treated with Folbex. Average mite drop per colony was 1682 and 1489 , respectively, in each group. The percentage mortality was not determined.

After extended laboratory screening of essential oils, Hoppe [42] evaluated the effect of the passive evaporation of 5,10 and $15 \mathrm{~mL}$ of clove and wintergreen oil from soft cardboard in normal colonies. Evaporation of $5 \mathrm{~mL}$ of either oil produced no effect. Evaporation of $10 \mathrm{~mL}$ of clove oil produced mite and bee mortalities of 47 and $27 \%$, respectively, while evaporation of $10 \mathrm{~mL}$ of wintergreen oil resulted in mortalities of 72 and $2 \%$, respectively. Evaporation of $15 \mathrm{~mL}$ of clove oil produced mite and bee mortalities of 92 and $50 \%$, respectively, compared to 95 and $7 \%$, respectively, with $15 \mathrm{~mL}$ of wintergreen oil. Both higher dosages led to behavioral disturbances of bees. Later, Hoppe and Ritter found that two combined treatments of brood-free colonies consisting of $5 \mathrm{~mL}$ of wintergreen oil (methyl-salycilate) and a 15 -min thermal treatment of $54{ }^{\circ} \mathrm{C}[11,43]$ resulted in a mite mortality of $93 \%$ and were well supported by the bees. A similar combination of treatments, but with a 30-min thermal treatment in colonies with brood, caused $31 \%$ mortality of adult mites after 5 days and blocked the reproduction in $69 \%$ of the mites, compared to $23 \%$ infertile mites before treatment [13].

Neem oil from seed-kernel showed a repellent effect and a high brood mortality under laboratory conditions [12]. However, passive evaporation of $10 \mathrm{~g}$ of neem oil every 3 weeks from a petri dish from below the brood from the middle of July until the beginning of winter, had no effect on bee and mite populations [12].

Colin [18] compared an aerosol application of water emulsions of $1 \%$ thyme oil (main ingredients p-cymene and thymol) and $0.5 \%$ sage oil (main ingredients: camphor, $\alpha$-thujone and eucalyptol) with the 
application of a $0.25 \%$ Amitraz solution in colonies having a small amount of brood. The aerosol treatment applied with warm air through the flight hole was carried out for $1 \mathrm{~min}$ and was repeated four times at intervals of 3-4 days. The mixture of thyme and sage oils resulted in $95 \%$ mite mortality compared to $99 \%$ mortality obtained with Amitraz. This mixture was commercialized under the name of BIOLOGIC ${ }^{\text {बi. }}$. Liebig [57] tested this product in brood-free colonies in November. Four, 1-min treatments at intervals of $3-4$ days with $100 \mathrm{~mL}$ of BIOLOGIC $V^{\circledR}$ per $1.5 \mathrm{~L}$ deionized water were carried out, essentially as described by Colin [18]. Mite mortality was about $10 \%$. The different efficiencies in these two trials was explained as a possible consequence of different compositions of the essential oil used and serves to illustrate the problems arising from not standardizing the essential oils, as previously mentioned. The thymol content of thyme oil of different origins and chemotypes varies between 5 and $40 \%$ [20]. Under the subtropical conditions of the coastal plain of Israel, Gal et al. [34] treated colonies in spring with $20 \%$ solution of oregano oil. Colonies with brood occupying one super were treated for 25 days with a piece of cardboard $(35 \times 50 \times 0.2 \mathrm{~cm})$ soaked with a solution of $50 \mathrm{~mL}$ of oregano oil (20 and $33 \%$ in a 1:1 vol/vol ethanolparaffin mixture). The cardboard was placed on the top of the brood chamber. A 2nd piece of cardboard was placed on the bottom board in colonies with two hive bodies. The average mortality was $82 \%$, while with $33 \%$ solutions, mortality was $91 \%$. Treatments at higher temperatures produced harmful effects such as robbing and absconding. Therefore, this method was recommended as a spring treatment during the citrus honey flow. Le Tu Long [55] obtained $99 \%$ mite mortality with a combined treatment of marjoram oil and $15 \%$ formic acid for 28 days. Seven treatments of $15 \%$ formic acid, the first one being $1.5 \mathrm{~L}$ and the subsequent ones $0.5 \mathrm{~L}$ each, were applied on the bottom board at 4-day intervals (total of $4.5 \mathrm{~L}$ of $15 \%$ formic acid). At the same time seven treatments of marjoram oil, each consisting of $3 \mathrm{~mL}$ oil applied on two wooden strips on top of the brood chamber, were made (total of $21 \mathrm{~mL}$ of marjoram oil). In Vietnam, the same application with a treatment period of only 24 days and application intervals of 3 days, showed $98 \%$ efficiency. No brood and bee losses were observed. However, this method is very material and time-consuming.

Other treatments with essential oils have been reported in the apicultural press and trade-journals, e.g. the use of Japanese medicinal plant oil [71] and the use of wintergreen oil, alone or in blends with linseed, pennyroyal, spearmint or tea-tree oil, and blends of patchouli with spearmint oil [2, 78]. However, most of these trials were not carried out under standardized test conditions and the efficacy of these treatments remains uncertain.

\subsection{Components of essential oils}

\subsubsection{Thymol}

Thymol is the only essential oil component widely used in apiculture that consistently exhibits high varroacidal activity and that is well tolerated by bees. It was first used against $A$. woodi [52]. Mikijuk [73] tested the varroacidal activity of thymol in bee colonies. He used $0.25 \mathrm{~g}$ per space in between combs and obtained mite mortality of $55 \%$. Mikijuk [72] found that while thymol evaporation increases greatly with increasing temperature or evaporation area, it was not influenced by air humidity. It was recommended that weak colonies should not be treated when temperatures are greater than $27-30^{\circ} \mathrm{C}$.

Impressed by the widespread use of thymol in combination with drone brood removal in Yugoslavia, Marchetti et al. [69] tested the application of $15 \mathrm{~g}$ powdered thymol suspended in a small gauze bag between two outer brood combs (table IV). Other 
studies with powdered thymol employing different quantities and application intervals during different seasons of the year have been conducted by workers in Italy and Spain ([17, 31, 33, 39, 40, 62], see table $I V)$. The average mite mortality varied from 66 to $98 \%$. In spite of the differences in the application methods, high mite mortality combined with low colony-to-colony variability was observed. Liebig [60] and Bollhalder [10] melted thymol and poured the solution on a viscose sponge, which was subsequently placed on the brood combs. The efficiency was comparable to that of the powder application (table IV). Marchetti et al. [69] and Lodesani et al. [62], however, have reported low mortality with thymol.

Knobelspies [51] developed a continuous treatment method with thymol. A small chamber is placed between the brood combs, and thymol evaporates through evaporation slots. Twelve grams of thymol are supplied in May and again in August. Although there are no published results on trials carried out under controlled conditions, anecdotal reports on the long-term use of this method claim that $V$. jacobsoni populations are maintained below economic injury levels, provided that there is no mite re-invasion.

\subsubsection{Api Life VAR ${ }^{\circledast}$}

Api Life VAR ${ }^{\circledR}$ (Chemicals LAIF, Italy) is composed of a porous ceramic carrier (florist block material $5 \times 9 \times 1 \mathrm{~cm}$ ) impregnated with a mixture of thymol $(76 \%)$, eucalyptol $(16.4 \%)$, menthol $(3.8 \%)$ and camphor $(3.8 \%)$. The vermiculite tablet is laid on the upper part of the brood combs. After 2-4 weeks of application, a second tablet is placed in the hive for the same period. In 14 of 22 applications $([14,15,22,35,46$, $50,59,65,76,77,80,84,88,91]$, Mutinelli et al., unpublished data) mite mortality was greater than $90 \%$ (table $V$ ). At normal depth, one-story bee hives, a higher efficacy was achieved than in larger (oversized) one-story hives and in multiple-story hives
$[50,59,84]$. When evaporation rate, and hence dosage, are increased, the efficacy is also increased [15, 84]. Efficacy also increases with increased treatment duration [50]. Treatments applied at the bottom of hives produced insufficient control $[50,59]$.

All components do not contribute to the varroacidal activity of Api Life VAR ${ }^{\circledR}$. The presence of camphor had no influence on the treatment efficiency $[50,84,91]$. Also, the concentration of menthol and eucalyptol in the hive [50] was much lower than necessary for good mite toxicity [49], while the thymol hive concentration measured has caused $100 \%$ mite toxicity in laboratory trials (see section 3.1). Thus, we can assume that thymol is the active ingredient of this formulation. This conclusion is supported by other trials $[10,60]$ where treatments with pure thymol, applied under similar conditions and with comparable amounts to the ones used with Api Life VAR ${ }^{\circledR}$, resulted in a comparable efficacy.

Low mite mortality has been reported with this product in some studies. This has been explained as a result of either a treatment period of insufficient duration or of low temperatures that do not allow for adequate evaporation (table V). Also, considerable colony-to-colony variability in efficacy, even within the same apiary, has been observed. Therefore, due to the limited reliability of the product, it has been suggested that it be used in combination with other measures such as drone brood removal, formation of nucleus colonies, and the application of oxalic acid or other varroacides during brood-free periods [46-48, 65, 77]. The same conclusion applies to the other thymol treatments. Further research, however, may help define the conditions under which thymol treatments can be relied upon for adequate control of $V$. jacobsoni.

During treatments with Api Life VAR ${ }^{\circledR}$, bees remove feed and brood in the vicinity of the applied product. Also, some colonies have difficulties taking supplementary feed during the treatment period $[46,59,76,80$, 


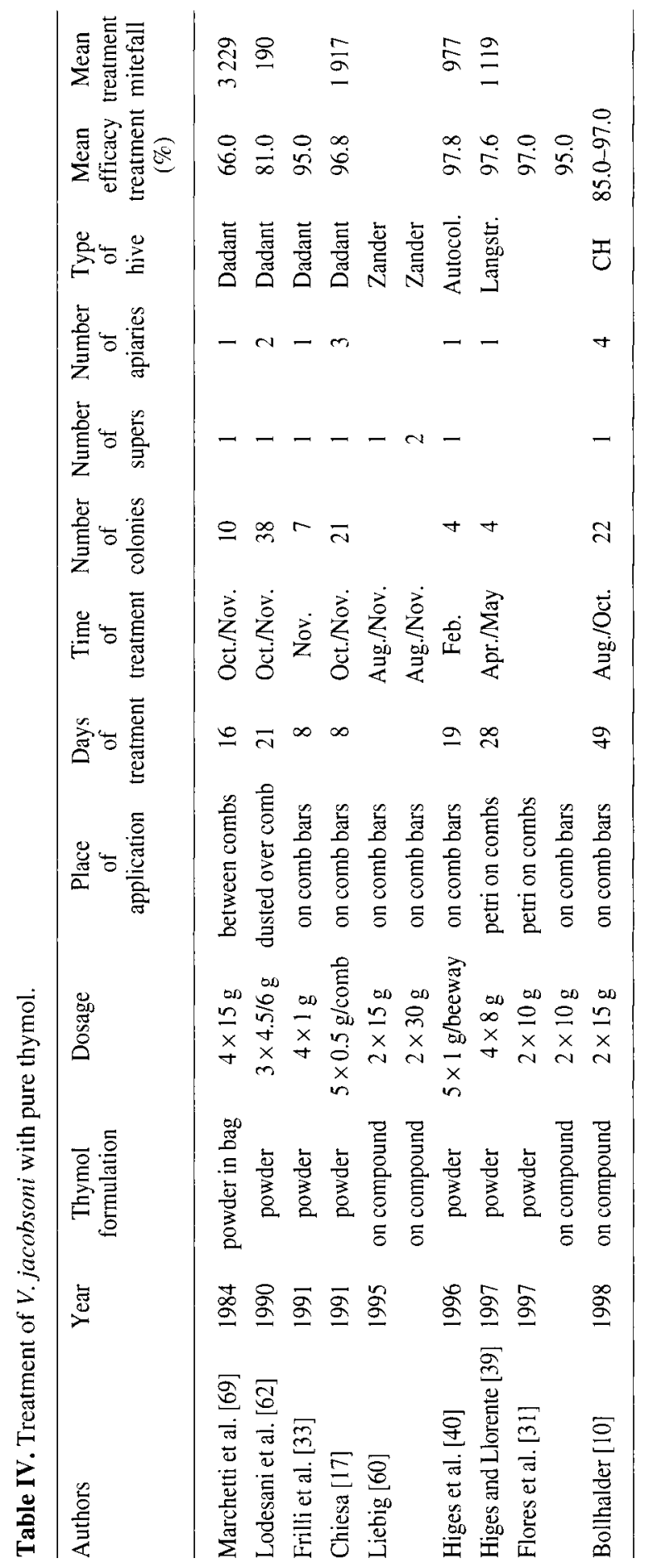




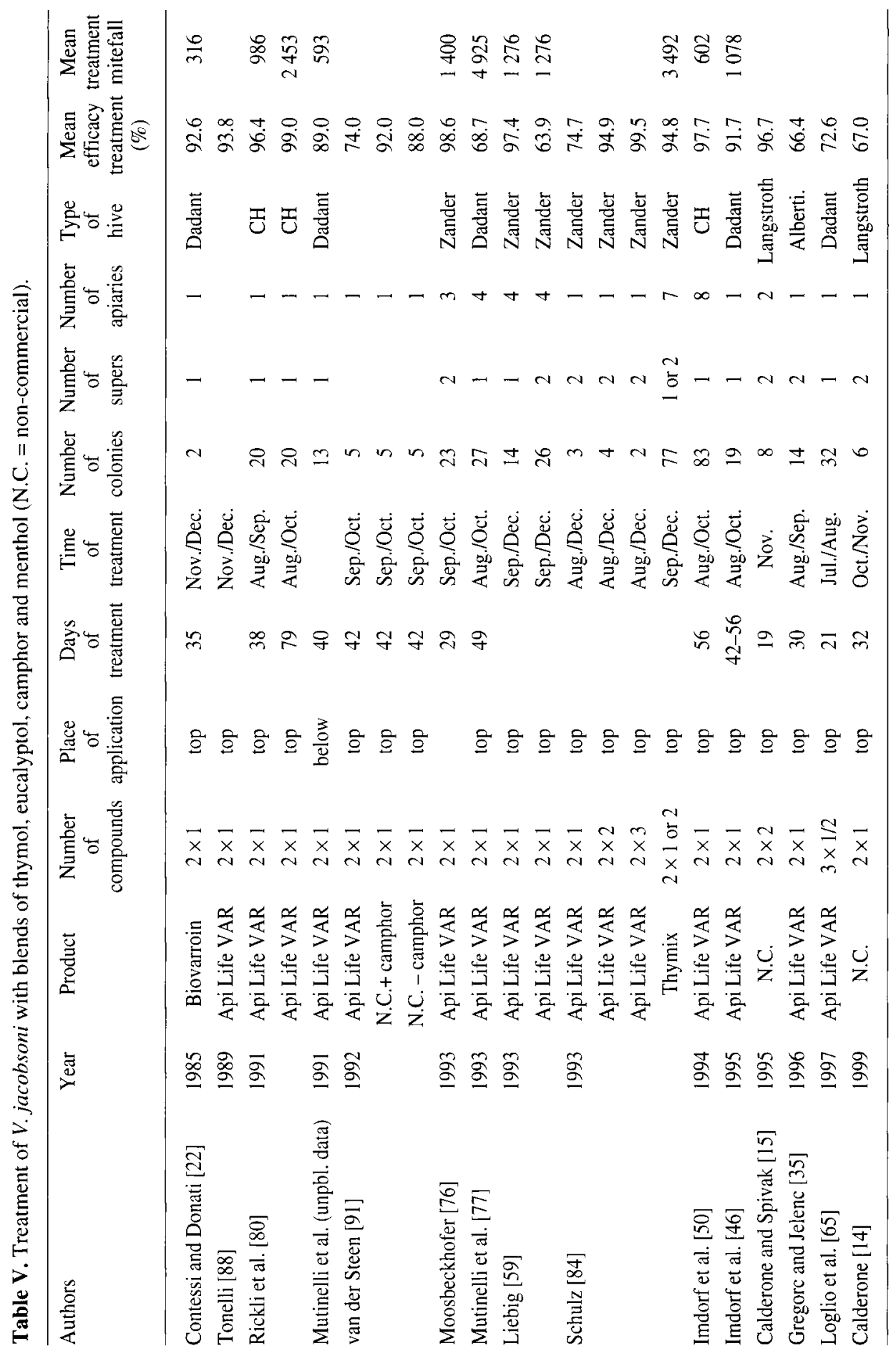


84]. Therefore, winter feed, when necessary, is best given before the treatment. Moosbeckhofer [76] observed negative effects of Api Life VAR ${ }^{\circledR}$ treatments on colony development, as well as stimulation of robbing and increased aggressiveness. The first two effects mentioned were not reported in other studies.

\subsubsection{Other thymol blends}

Calderone et al. [16] evaluated the application of different thymol blends (1:1 wt/wt) on colonies in three different apiaries. Blends included thymol and linalool, thymol and eucalyptol, and thymol and citronellal. Two application rates, 25 and $12.5 \mathrm{~g} /$ application, were tested. The first application was replaced by a second after 14 days. Total treatment period was 28 days in the late-summer and autumn of 1994. They achieved an average mite mortality in the thymol-eucalyptol treatment groups of 56 and $49 \%$ for the higher and lower rates, respectively. Corresponding values were 43 and $38 \%$ for thymol and citronellal, and 40 and $30 \%$ for thymol and linalool. Rate effects were not statistically significant for any of the three blends. The overall low level of mortality was attributed to the large amounts of brood present during treatment, as a much higher efficacy of $96.7 \%$ was achieved with the application of a similar thymol blend on nearly broodless colonies [15].

\subsubsection{Menthol, camphor and linalool}

Sidorov et al. [86] reported an unquantified acaricidal activity of menthol in bee colonies, in addition to that of other essential oils. Menthol was also tested by Mikitjuk et al. [73]. Its efficacy was only $13 \%$, that of thymol was $55 \%(0.25 \mathrm{~g}$ per space in between combs used). Higes et al. [41] treated two groups of four broodless colonies over 4 weeks with either $30 \mathrm{~g}$ of menthol or $60 \mathrm{~g}$ of camphor. Menthol had an average efficiency of $20.5 \%$, which was not signif- icantly different from the control. The efficacy of camphor was $71.9 \%$. The results of the laboratory trials of Imdorf et al. [49] showed that menthol and camphor caused a high mite mortality at concentrations which were not toxic for bees. Thus, further trials to develop the optimal application mode are necessary to clarify whether this substance can successfully be used for mite control. Two applications of $17 \mathrm{~g}$ of linalool applied 14 days apart to brood-free colonies produced a mite mortality of only $27.4 \%$ [15]. The reason for this low efficacy may be due to the weak varroacide effect of this substance or it may require higher temperatures for a better evaporation and effectiveness.

\section{RESIDUES OF ESSENTIAL OILS}

Essential oils, and components thereof, have been used with varying degrees of success for mite control. However, there are few studies dealing with residues in honey and other hive products, and those that have been carried out were performed after the use of individual essential oil components, rather than after treatment with essential oils. Since essential oils are, themselves, complex blends of compounds, and since most honeys naturally contain many essential oil constituents as aroma components [67], analysis of residues after treatment with essential oils can be complicated and inconclusive. This can make compliance with EU and US governmental regulations difficult.

Residues are a significant concern, not only because of possible health considerations, but because of their possible effects on honey quality. According to EU regulation no. $2377 / 90$, thymol is in group II of the non-toxic veterinary drugs, which do not need a MRL (maximal residue limit). Essential oils are, however, odor-intensive substances and very small amounts in honey can alter its taste. When thymol is used for control of $V$. jacobsoni when there is no 
nectar flow in progress, residues found in honey vary from 0.02 to $0.48 \mathrm{mg} \cdot \mathrm{kg}^{-1}$ [6, $77,64,90]$. However, if thymol is used during nectar flow, there is considerable danger that residues may reach levels above the taste threshold. Bogdanov et al. [8] found that $1.1-1.6 \mathrm{mg}$ of thymol $\cdot \mathrm{kg}^{-1}, 5-10 \mathrm{mg} \cdot \mathrm{kg}^{-1}$ of camphor and $20-30 \mathrm{mg} \cdot \mathrm{kg}^{-1}$ of menthol can significantly alter honey taste. For this reason, in Switzerland a MRL value of $0.8 \mathrm{mg}$ thymol $\cdot \mathrm{kg}^{-1}$ was fixed. The treatment method of Knobelspiess [51] is used in different European countries. This method delivers thymol in the hive continuously throughout the entire year. Honeys harvested in bee hives treated with this method often have thymol residues higher than the Swiss MRL value of $0.8 \mathrm{mg} \cdot \mathrm{kg}^{-1}$ [7].

Bogdanov et al. [6], evaluated the effects of a long-term use of Api Life-VAR ${ }^{\otimes}$ (main ingredient thymol) on honey and wax residues. The thymol residues in honey and wax did not increase with increasing number of Api Life-VAR ${ }^{\circledR}$ treatments. Brood comb residues reached a relatively high level (average of $517 \mathrm{mg} \cdot \mathrm{kg}^{-1}$ ). However, if Api Life VAR ${ }^{\circledR}$ treatment is stopped, thymol rapidly evaporates from wax and after 1 year drops to near the limit of detection. In unopened, bottled honey, thymol, camphor and menthol remain stable for 2 years [6].

Menthol, another substance with a varroacidal activity [49], has been used for control of $A$. woodi in North America. After a 3-week treatment, a maximum of $18 \mathrm{mg} \cdot \mathrm{kg}^{-1}$ ) in honey and $2790 \mathrm{mg} \cdot \mathrm{kg}^{-1}$ ) in wax were detected [56]. This level is below the sensory threshold of menthol in honey.

\section{DISCUSSION}

New alternatives for the control of $V$. jacobsoni are necessary because of the rapid and widespread development of pyrethroid and organo-phosphate-resistant mite populations and because of the potential for contamination of hive products by these chemicals. Essential oils, and especially components of essential oils, may serve as alternatives or as adjuncts to traditional treatment measures. In extensive screening tests, many oils show significant acaricidal activity. Some oils are repellent to $V$. jacobsoni, others are attractive, and some cause mite mortality. However, very few of them have proven effective when applied in hives in field trials. Considerable variation in local environmental and colony conditions affect efficacy and make it difficult to predict the outcome of many treatments. Difficulty in obtaining standardized essential oils also affects treatment predictability. Only a combination of wintergreen oil and thermal treatment, an aerosol treatment of a thyme-sage oil mixture, and the passive evaporation of thymol, oregano oil and marjoram oil in combination with diluted formic acid have been successfully used for mite control (see sections 4.1 and 4.2). For several reasons, however, none of these treatments have been widely adopted by beekeepers, with the exception of thymol. Indeed, thymol and thymol blends are widely used to control $V$. jacobsoni in Europe and in most cases their varroacidal efficacy is greater than $90 \%$. In due time, different thymol-containing products will be available on the market. In laboratory tests, a high mite toxicity, combined with good bee tolerance, were demonstrated for a number of other components of essential oils (see section 3.1).

Identifying compounds with acceptable acaricidal activity but with low toxicity to honey bees is essential for providing candidate compounds for field trials. Future research can assist in this effort by focusing on the characterization of the doseresponse relationships between essential oils and 1) mite/bee toxicity, and 2) effects on mite behaviour. This procedure can serve as a powerful screening technique because it guides subsequent field research into the most productive avenues.

The development of effective delivery systems for essential oils remains one of the 
greatest roadblocks to their implementation as mainstream control measures. Highly volatile substances such as camphor are difficult to use, but formulations retarding the evaporation rate, e.g. special gels, might overcome this difficulty. Products with mixtures of different components with different modes of action, might also provide effective solutions. For example, substances that disrupt the mite's host location process may be effective in conjunction with substances that kill mites.

Residues pose another challenge to the use of essential oils. Most essential oils are mixtures of more than 50 components. Depending on the individual partition coefficients of the constituents, residues in honey and wax are to be expected. Residues in honey can lead to adverse effects on taste, while residues in wax can render it unsuitable for some applications. Quantitative residue analyses are required for product registration. The complex nature of many essential oils, combined with the fact that many essential oil components are naturally occurring in honey, makes such residue analysis difficult. Thus, the successful development of products employing essential oils can be extremely difficult unless the particular essential oil has been granted an exemption from tolerance. The use of individual components of essential oils makes residue analysis much easier and limits the potential for producing off-flavor honey. Long-term studies demonstrated that when used properly, residues of thymol in honey remain at low and safe levels.

Based on the available studies, relying solely on one treatment per bee season with essential oils or essential oil components can not be recommended as an effective and reliable method to maintain mite populations below the economic injury level. The challenge for future research is to optimize the use of essential oils and essential oil components and to incorporate the resulting products along with other measures for limiting mite populations such as cutting out of drone brood, trapping combs, formation of nucleus colonies or the use of organic acids $[47,48,58,82,81,94]$, into an integrated pest management strategy for the control of $V$. jacobsoni. Adapting these strategies to local climatic conditions, to diverse apicultural management practices and to beekeeping operations of varying sizes pose additional and significant challenges. Finally, resistance to essential oils may eventually develop, as it has with synthetic pesticides. Consideration must be given to the development of resistance management plans to maximize the useful life span of effective acaricides and delivery systems once they are developed.

\section{ACKNOWLEDGEMENT}

This review was supported in part by a grant from the USDA-CSREES Northeast-IPM Program (\#9704078) to NWC and by a grant from the NYS Department of Agriculture and Markets (\#C970001) to NWC.

Résumé - Utilisation des huiles essentielles dans la lutte contre Varroa jacobsoni, parasite des colonies d'abeilles. Le développement de la résistance des populations de Varroa jacobsoni et le spectre de la contamination des produits du rucher ont fortement stimulé la mise au point de nouvelles stratégies de traitement qui diminuent la possibilité d'un développement rapide de la résistance et l'accumulation de résidus. Cet article passe en revue l'utilisation des huiles essentielles (h.e.) et de leurs composants dans la lutte contre $V$. jacobsoni. «Huiles essentielles » est un terme générique qui désigne les composants liquides et hautement volatiles des plantes, marqués par une odeur forte et caractéristique. Les terpènes (principalement les monoterpènes) représentent la majeure partie (environ $90 \%$ ) de ces composants. L'eucalyptol, le camphre, le menthol et le thymol sont des monoterpènes typiques. Chaque espèce de plante tend à avoir une composition en h.e. unique. 
Pourtant, certaines espèces ont des variétés dénommées chémotypes, dont la composition en h.e. varie. On a utilisé les méthodes de criblage au laboratoire pour tester sur $V$. jacobsoni et sur les abeilles la toxicité, la répulsivité, l'attractivité, ainsi que les effets sur la reproduction, des h.e. et de leurs composants. Au total, c'est plus de 150 h.e. et composants d'h.e. qui ont été testés (tableaux $I-I I I)$, mais peu d'entre eux se sont montrés efficaces lors de leur utilisation sur ruches en conditions de terrain. Une variation énorme des conditions du milieu local et des colonies, ainsi que la difficulté d'obtenir des h.e. standardisées, rendent difficile la prévision du résultat des nombreux traitements. Les résidus dans le miel peuvent conduire à des effets négatifs sur le goût. L'analyse quantitative des résidus est exigée pour l'enregistrement du produit. La nature complexe de beaucoup d'h.e. et le fait que de nombreux composants des h.e. sont présents à l'état naturel dans le miel font que l'analyse des résidus est difficile. Néanmoins ces difficultés disparaissent lorsqu'on utilise individuellement les composants des h.e. La plupart sont volatils et disponibles sur le marché à prix raisonnables. Parmi tous les composants testés des h.e., c'est le thymol qui a eu le meilleur résultat en apiculture pratique. Dans les essais en champ le thymol pur (tableau $I V$ ) et les mélanges à base de thymol (tableau $V$ ) ont montré une activité varroacide élevée. Le thymol est bien toléré par les abeilles. Si les traitements sont effectués en dehors de la période de miellée, les résidus de thymol dans le miel n'augmentent pas lorsqu'on multiplie les traitements et restent sous le seuil de détection gustative, qui se situe entre 1,1 et $1,6 \mathrm{mg} \cdot \mathrm{kg}^{-1}$. Selon les études on a trouvé des résidus compris entre 0,02 et $0,48 \mathrm{mg} \cdot \mathrm{kg}^{-1}$. Mais les traitements au thymol pendant la miellée peuvent conduire à des résidus plus élevés qui modifient le goût du miel. Le thymol, de même que d'autres monoterpènes tels que le menthol et le camphre, ont le statut GRAS (generally recognized as safe, généralement reconnu comme sans danger), de la FAO aux concentrations allant jusqu'à $50 \mathrm{mg} \cdot \mathrm{kg}^{-1}$. Les résidus de ces substances dans le miel ne posent donc pas de problème toxicologique. Après un traitement au thymol les résidus dans la cire sont 1000 fois plus élevés que dans le miel, mais ils diminuent rapidement par évaporation dès que le traitement est arrêté. D'après les études disponibles, un seul traitement à base d'h.e. ou d'un composant d'h.e. est généralement insuffisant pour maintenir la population d'acariens en dessous du seuil de dégât économique pendant toute la saison. Des efforts sont donc nécessaires pour intégrer ces produits, ainsi que d'autres mesures pour limiter les populations d'acariens tels que l'élimination du couvain de mâles, les rayons pièges, la formation de nuclei et l'utilisation d'acides organiques, dans une stratégie de lutte intégrée contre $V$. jacobsoni. (C) Inra/DIB/AGIB/ Elsevier, Paris

\section{Apis mellifera / Varroa jacobsoni / lutte chimique / huile essentielle / résidu}

\section{Zusammenfassung - Ätherische Öle zur Bekämpfung von Varroa jacobsoni in Honigbienenvölkern. Die Entwicklung von} Varroazidresistenzen und das Ausma $\beta$ verschiedenartigster Verunreinigungen von Bienenprodukten stellt eine dringende Herausforderung zur Entwicklung neuer Behandlungsstrategien dar, durch die diese Nachteile eingegrenzt werden können. Der vorliegende Artikel gibt einen Überblick über die Nutzung von ätherischen Ölen oder ihrer Komponenten zur Bekämpfung von Varroa jacobsoni. Als 'ätherische Öle' werden hierbei flüssige, hochflüchtige Pflanzenbestandteile zusammengefasst, die durch intensiven und charakteristischen Duft gekennzeichnet sind. Den Hauptanteil stellen mit etwa $90 \%$ Terpene, zumeist Monoterpene. Typische Monoterpene sind zum Beispiel Eukalyptol, Kampfer, Menthol und Thymol. Die Mischung ätherischer Öle ist zumeist für die jeweilige Pflanzenart einheitlich. Aller- 
dings bilden einige Pflanzenarten Varietäten aus, sogenannte Chemotypen, die sich in der Zusammensetzung ihrer ätherischen Öle unterscheiden.

Toxische Eigenschaften oder die Wirkungen als Attraktans, Repellent oder auf die Reproduktion wurde in Labortests untersucht. Insgesamt wurden hierbei bisher über 150 verschiedene ätherische Öle oder ihre Komponenten getestet (Tabelle I-III). Allerdings erwiesen sich nur wenige als wirksam, sobald sie in Feldversuchen in Völkern angewandt wurden. Die erheblichen Unterschiede in den örtlichen Umgebungsbedingungen und zwischen den Völkern beeinflussen die Wirksamkeit und erschweren eine zuverlässige Aussage über den zu erwartenden Behandlungserfolg. Hinzu kommt die Schwierigkeit, standardisierte ätherische Öle zu erhalten. Die Rückstände im Honig können den Geschmack negativ beeinflussen. Zur Registrierung eines Behandlungsmittels sind quantitative Rückstandsanalysen erforderlich. Diese wird durch die komplexe Zusammensetzung vieler ätherischer Öle und durch die Tatsache erschwert, daß viele der Komponenten auch natürlicherweise im Honig vorkommen. Die Nutzung einzelner Komponenten der ätherischen Öle ist allerdings nicht von diesen Schwierigkeiten begleitet. Die meisten Komponenten sind flüchtig und zu annehmbaren Preisen auf dem Markt erhältlich.

In der praktischen Imkerei hat sich von allen untersuchten Komponenten ätherischer Öle Thymol am besten bewährt. In Freilandversuchen zeigten Thymol (Tabelle IV) und Thymolmischungen (Tabelle $V$ ) eine hohe varroazide Wirksamkeit. Andererseits wird Thymol von den Bienen gut vertragen. Solange die Thymolbehandlungen außerhalb der Trachtzeit durchgeführt werden, steigen die Thymolrückstände auch mit zunehmender Anzahl von Anwendungen nicht an und bleiben weit unterhalb der geschmacklich wahrnehmbaren Schwelle von 1,1 bis $1,6 \mathrm{mg} \cdot \mathrm{kg}^{-1}$. In verschiedenen Untersuchungen wurden Rückstände im Honig zwischen 0.02 und $0.48 \mathrm{mg} \cdot \mathrm{kg}^{-1}$ gefunden. Allerdings können Thymolanwendungen während der Trachtzeiten zu höheren Rückständen und verändertem Geschmack des Honigs führen. Thymol sowie andere milbengiftige Monoterpene wie Menthol und Kampfer werden bis zu $50 \mathrm{mg} \cdot \mathrm{kg}^{-1}$ generell als sicher angesehen (Status FAO GRAS ). Rückstände dieser Substanzen im Honig sind daher toxikologisch ohne Belang. Thymolruickstände im Wachs sind nach einer Behandlung um einen Faktor von 1000 höher als im Honig, nach der Anwendung vermindern sie sich allerdings rasch durch Verdunstung.

Nach den bestehenden Untersuchungen ist eine einzige Behandlung mit ätherischen Ölen generell nicht ausreichend, um die Milbenpopulation uiber eine ganze Saison unterhalb der ökonomischen Schadensschwelle für die Bienenvölker zu halten. Zur Begrenzung der Milbenpopulation sind daher im Rahmen einer integrierten Bekämpfungsstrategie zusätzliche Maßnahmen erforderlich, wie das Ausschneiden von Drohnenbrut, Fangwaben, Jungvolkbildung oder die Anwendung organischer Säuren. (C) Inra/ DIB/AGIB/Elsevier, Paris

\section{Apis mellifera / Varroa jacobsoni / ätherische Öle / Wirksamkeitstests / Ruickstände}

\section{REFERENCES}

[1] Adams R., Identification of Essential Oils by Ion Trap Mass Spectroscopy, Academic Press, 1989.

[2] Amrine J.W., Stansy T.A., Skidmore R., New mite controls investigated, Am. Bee J. (1996) 652-654.

[3] Angelloz-Nicoud E., Treatment of acarine disease with methyl salicylate, Bee World 10 (1930) $12-14$

14] Bassand D., Du bon ou mauvais usage du fluvalinate contre Varroa jacobsoni: Etude des risques d'apparition d'une résistance, La Santé de l'abeille (1993) 113-117.

[5] Baxter J., Eischen F., Pettis J., Wilson W.T., Shimanuki H., Detection of fluvalinate-resistant Varroa mites in U.S. honey bees, Am. Bee J. 138 (1998) 291. 
[6] Bogdanov S., Imdorf A., Kilchenmann V., Residues in wax and honey after Api Life VAR treatment, Apidologie 29 (1998) 513-524.

[7] Bogdanov S., Imdorf A., Kilchenmann V., Fluri P., Rückstände in Honig nach Verwendung des Thymolrähmchens gegen die Varroa, Schwciz. Bienenztg. 121 (1998) 224-226.

[8] Bogdanov S., Kilchenmann V., Fluri P., Bühler U.,

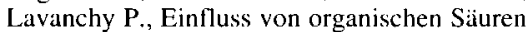
und Komponenten von ätherischen Ölen auf den Honiggeschmack, Bienenwelt 40 (1998) 232-236.

[9] Bogdanov S., Kilchenmann V., Imdorf A., Acaricide residues in some bee products, J. Apic. Res. 37 (1998) 57-67.

[10] Bollhalder F., Thymovar zur Varroabekämpfung, Schweiz. Bienenztg. 121 (1998) 148-151.

[11] Borgstädt M., Alternative Varroabekämpfung. Mit Warmluft und Essenzen gegen die Varroa, Schweiz. Bienenztg. 114 (1991) 340-344.

[12] Bunsen J.D., Experimentelle Untersuchungen zur Bekämpfung der Milbe Varroa jacobsoni Oud., einem Ektoparasit der Honigbiene (Apis mellifera L.) mit Stoffen natürlicher Herkunft, Dissertation, Justus-Liebig-Universität Giessen, 1991

[13] Bunsen J.D., Ritter W., Wirkung der kombinierten Thermobehandlung mit Wintergrünöl in die verdeckelte Brut, Allg. Disch. Imkerztg. (1991) 12-15.

[14] Calderone N.W., Evaluation of formic acid and thymol-based blend of natural products for the control of Varroa jacobsoni in colonies of the honey bee, Apis mellifera, J. Econ. Entomol. (1999) in press

[15] Calderone N.W., Spivak M., Plant extracts for control of the parasitic mite Varroa jacobsoni (Acari: Varroidae) in colonies of the Western honey bee (Hymenoptera: Apidae), J. Econ. Entomol. 88 (1995) 1211-1215.

[16] Calderone N.W., Wilson W.T., Spivak M., Plant extracts used for control of the parasitic mites Varroa jacobsoni and Acarapis woodi in colonies of Apis mellifera, J. Econ. Entomol. 90 (1997) 1080-1086.

[17] Chiesa F., Effective control of varroatosis using powdered thymol, Apidologie 22 (1991) 135-145.

[18] Colin M.E., Essential oils of Labiatae for controlling honey bee varroosis, J. Appl. Entomol. 110 (1990) 19-25.

[19] Colin M.E., Ciavarella F., Otero Colina G., Belzunces L.P., A method for characterizing the biological activity of essential oils against $\mathrm{Var}$ roa jacobsoni, in: Matheson A. (Ed.), New Perspectives on Varroa, International Bee Research Association, Cardiff, UK, 1994, pp. 109-114.

[20] Colin M.E., Ducos de Lahitte J., Larribau E., Boue T., Activité des huiles essentielles de Labiées sur Ascosphaera apis et traitement d'un rucher, Apidologie 20 (1989) 221-228.
[21] Colombo M., Lodesani M., Spreafico M., Resistance of Varroa jacobsoni to fluvalinate. Preliminary results of investigations conducted in Lombardy, Ape Nostra Amica 15 (1993) 12-15.

[22] Contessi A., Donati R., Esperienze 'sul campo' nel controllo della varroatosi, Apicolt. nat. La Citta delle Api ( 1985) 25-28.

[23] Crane E., Fresh news on the Varroa mite, Bee World 60 (1979) 8 .

[24] De Jong D., Mites: Varroa and other parasites of brood, in: Morse R.A. Flottum K. (Eds.), Honey Bee Pests, Predators and Disease, 2nd ed., Cornell University Press, Ithaca, NY, USA, 1997.

[25] De Jong D., Gonçalves L.S., Morse R.A., Dependence on climate of the virulence of Varroa jacobsoni, Bee World 65 (1984) 117-121.

[26] De Jong D., Morse R.A., Eickwort G.C., Mite pests of honey bees, Annu. Rev. Entomol. 27 (1982) 229-252.

[27] Eischen F.A., Varroa resistance to Fluvalinate, Am. Bee J. (1995) 815-816.

[28] Eischen F.A., Wilson W.T., The effect of natural products smoke on Varroa jacobsoni, Am. Bee J. (1997) 222-223.

[29] Eischen F.A., Wilson W.T., The effect of natural products smoke on Varroa jacobsoni: an update, Am. Bee J. ( 1998$) 293$

[30] Faucon J.P., Drajnudel P., Fleche C., Mise en évidence d'une diminution de l'efficacite de l'Apistan $\left.{ }^{(}\right)$utilise contre la varroose de l'abeille (Apis mellifera L), Apidologie 26 (1995) 291-296.

[31] Flores J.M., Recherches sur les traitements alternatifs dans le sud de l'Espagne. I. Acide formique, thymol, rotenone - substances acaricides naturelles, Les Carnets du CARI (1997) 5-8.

[32] Flores J.M., Puerta F., Padilla F., Campano F., Ruiz J.A., Ruiz. D., Lucha contra la varroasis. Situacion actual y perspectivas de futuro, Vida Apicola (1994) 36-43

[33] Frilli F., Milani N., Barbattini R., Greatti M., Chiesa F., Iob M., Dagaro M., The effectiveness of various acaricides in the control of Varroa jacobsoni and their tolerance by honeybees, in: Prota R., Floris I. (Eds), Proceedings of the Current State and Development of Research in Apiculture, 25-26 October, Istituto di Entomologia Agraria, Universita degli Studi di Sassari, Sassari, Italy, 1991, pp. 59-77

[34] Gal H., Slabezki Y., Lensky Y., A preliminary report on the effect of origanum oil and thymol applications in honey bee (Apis mellifera L.) colonies in a subtropical climate on population levels of Varroa jacobsoni, BeeScience 2 (1992) $175-180$

[35] Gregorc A., Jelenc J., Control of Varroa jacobsoni Oud. in honey bee colonies using ApilifeVar, Zbornik Veterinarske Fakultete Univerza Ljubliana 33 (1996) 231-235. 
[36] Griffiths D.A.. Bowman C.E.. World distribution of the mite Varroa jacobsoni, a parasite of honeybees, Bee World 62 (1981) 154-163.

137] Guenther E., The Essential Oils: Individual Essential Oils of Plant Families, Krieger Publications \& Co., 1992.

1381 Hay R., Waterman P., Volatile Oil Crops: Their biology, Biochemistry and Production, John Wiley \& Sons, 1993.

[39] Higes P.M., Llorente J., Timol: Ensayo de eficacia en el control de varroosis en colmenas de producción. Vida Apicola 81 (1997) 14-17.

[40] Higes P.M., Suarez R.M., Test of the efficacy of thymol in the control of varroosis in the honey bee (Apis nellifera), Colmenar (1996) 29-31.

141] Higes P.M., Suarez R.M., Llorente J., Comparative ficld trials of Varroa mite control with different components of essential oils (thymol, menthol and camphor), Res. Rev. Parasitol. 57 (1997) 2 i-54.

142] Hoppe H., Vergleichende Untersuchungen zur biotechnischen Bekämpfung der Varroatose, Dissertation, Justus-Liebig-Universität Giessen, 1990.

143] Hoppc H., Ritter W, Erste Ergebnisse zur Bekämpfung der Varroatose mit einem thermischen Umluftverfahren in Kombination mit Wintergrüinöl, Die Bicne (1989) 390-393.

[44] Hoppe H., Schley P., Varroa-Falle mit Lockstoffen möglich?, Die Biene 120 (1984) 387-388.

[45| Ian Tsin-He, Les particularites biologiques de l'acarien Varroa jacobsomi (Oud.), Kounchong Zhishi 9 (1965) 40-4l (in Chinese).

|46| Imdorf A., Bogdanov S., Kilchenmann V., Maquelin C., Apilife VAR: A new varroacide with thymol as the main ingredient, Bee World 76 (1995) 77-83.

[47] Imdorf A., Charrière J.D., Wie können die resistenten Varroamilben unter der Schadensschwelle gehalten werden?, Schweiz. Bienenztg. 121 (1998) 287-291.

148] Imdorf A., Charrière J.D., Maquelin C., Kilchenmann V., Bachofen B., Alternative Varroa control, Am. Bee J. 136 (1996) 189-193.

149] Imdorf A., Kilchenmann V., Bogdanov S., Bachofen B., Beretta C., Toxic effects of thymol, camphor, menthol and eucalyptol on Varroa jacobsoni Oud and Apis mellifera $\mathrm{L}$ in a laboratory test, Apidologie 26 (1995) 27-31.

[50] Imdorf A., Kilchenmann V., Maquelin C., Bogdanov S., Optimierung der Anwendung von 'Apilife VAR' zur Bekämpfung von Varroa jacobsomi Oud. in Bienenvölkern, Apidologie 25 (1994) 49-60.

151] Knobelspies F., Die Varroamilben und die Thymolanwendung im Sommer, Allg. Dtsch. Imkerztg. (1996) 20-21.
152] Kostecki R., Untersuchungen über die Anwendung von Thymol bei der Behandlung der Milbenkrankheit der Bienen während der Ueberwinterungszeit, Tierärztliche Umschau (1976) $398-401$.

153] Kraus B., Untersuchungen zur olfaktorischen Orientierung von Varroa jacobsoni Oud. und deren Störung durch ätherische Öle, Dissertation, Goethe-Universität, Frankfurt, Fachbereich Biologie, 1990.

154] Kraus B., Koeniger N., Fuchs S., Screening of substances for their effect on Varroa jacobsoni: attractiveness, repellency, toxicity and masking effects of etheral oils, J. Apic. Res. 33 (1994) 34-43.

|55| Le Tu Long, Die Kombinationsanwendung von Ameisensäure und Majoranöl zur Bekämpfung der Varroatose unter gemässigten (Deutschland) und tropischen (Vietnam) Klimabedingungen, Dissertation, Justus-Liebig-Universität Giessen, 1998.

[56] Li M., Nelson D.L.. Sporns P.. Determination of menthol in honey by gas chromatography, J. Assoc. Off. Anal. Chem. Int. 76 (1993) 1289-1295.

1571 Liebig G., Behandlung von varroabefallenen Bienenvölkern mit Biologic V, Dtsch. Imker J. (1991) 170-171.

[58] Liebig G., Meine Betriebsweise mit der Varroa. Varroabekämpfung - ein fester Bestandteil der Völkerführung, Dtsch. Imker J. 2 (1991) 297-304

[59] Liebig G., Varroabekämpfung mit Apilife-VAR, Bienenpflege (1993) 247-249.

[60] Liebig G., 'Es geht auch ohne!' Kurzfassung des Vortrages auf dem Apisticus-Tag am 21 Januar 1995 in Münster, Dtsch. Bienen J. (1995) 4-7.

[6!] Lodesani M., Variabilità dell'efficacia terapeutica ottenuta con trattamento di Perizin, L'Ape Nostra Amica (1996) 4-9.

[62] Lodesani M., Bergomi S., Pellacani A., Carpana E., Rabitti T., A comparative study on the efficacy of some products for controlling Varroa, and determinations of their residues, Apicoltura (1990) 105-130.

[63] Lodesani M., Colombo M., Spreafico M., Ineffectiveness of Apistan ${ }^{\circledR}$ treatment against the mite Varroa jacobsoni Oud in several districts of Lombardy (Italy), Apidologie 26 (1995) 67-72.

[64] Lodesani M., Pellacani A., Bergomi S., Carpana E., Rabitti T. Lasagni P., Residue determination for some products used against Varroa infestation in bees, Apidologie 23 (1992) 257-272.

|65| Loglio G., Lotta alla Varroa con Api Life Vare Perizin: tre anni di esperienze, Apic. Mod. 88 (1997) 17-26.

[66] Loglio G., Plebani G., An appraisal of apistan effectiveness, Apic. Mod. 83 (1992) 95-98.

[67] Maga J.A., Honey flavor, Lebensm.-Wiss. u. Technol. 16 (1983) 65-68. 
[68] Marchetti S., Barbattini R., D’ Agaro M., Prove premilinari sull'impiego di alcune specie vegetali nel controllo di Varroa jacobsoni oud., Atti del II convegno internazionale dell'apicultura, Lazise (1983) 71-77.

[69] Marchetti S., Barbattini R., D’Agaro M., Comparative effectiveness of treatments used to control Varroa jacobsoni, Apidologie 15 (1984) 363-378.

[70] Matheson A., First documented findings of Var roa jacobsoni outside its presumed natural range, Apiacta 30 (1995) 1-8.

[71] Maul V., Kurzbericht über Versuche zur Varroatosebekämpfung mit Japanischem Heilpflazenöl, Die Biene 118 (1982) 388-390.

[72] Mikityuk V.V., Efficiency of thymol against Varroa disease, Veterinariya Moscow, USSR (1983) 43-44 (in Russian).

[73] Mikityuk V.V., Grobov O.F., Trials of chemical for controlling Varroa jacobsoni infestations of bees, Tr. Vses. Instit. Eksp. Vet. 50 (1979) 120-125 (in Russian).

[74] Milani N., La resistenza agli acaricidi: un problema emergente nella lotta contro la Varroa, Ape Nostra Amica 15 (1992) 4-5, 7-11.

[75] Milani N., The resistance of Varroa jacobsoni Oud. to pyrethroids: a laboratory assay, Apidologie 26 (1995) 415-429.

[76] Moosbeckhofer R., Versuche mit Api-Life-VAR zur Bekämpfung der Varroamilbe, Bienenwelt 35 (1993) 161-166.

[77] Mutinelli F., Irsara A., Cremasco S., Piro R. Control of varroatosis by means of APILIFEVAR in the Varroa detection tray, Apic. Mod. 84 (1993) 111-117 (in Italian).

[78] Noel B., Amrine J., More on essential oil for mite control, Am. Bee J. (1996) 858-859.

[79] Ohloff G., The Fascination of Odors and their Chemical Perspectives, Scent and Fragrances, Springer Verlag, 1994.

[80] Rickli M., Imdorf A., Kilchenmann V., VarroaBekämpfung mit Komponenten von ätherischen Ölen, Apidologie 22 (1991) 417-421.

[81] Ritter W., Rüickstandsfreie Bienenhaltung mit integrierten Bekämpfungskonzepten, Allg. Dtsch. Imkerztg. (1996) 6-9.

[82] Rosenkranz P., Alternative Konzepte der Varroatose-Bekämpfung, Imkerfreund (1992) 5-14.
[83] Sammataro D., Degrandi-Hoffmann G., Needham G., Wardell G., Some volatile plant oils as potential control agents for Varroa mites (Acari: Varroidae) in honey bee colonies (Hymenoptera: Apidea), Am. Bee J. 138 (1999) 681-685.

[84] Schulz S., Anwendung thymolhaltiger Varroazide bei Magazinvölkern, Dtsch. Bienen J. I (1993) 18-20.

[85] Shutov N.N., Study of acaricidal properties of systemic phytopreparations in varroatosis of bees, Soviet Agric. Sci. (1989) 52-54.

[86] Sidorov N.G., Stolbov N.M., Platukhina N., The effect of volatile oils of higher plants on the Varroa parasite of honeybees, Veterinariya, Moscow, USSR (1977) 65-68 (in Russian).

[87] Smirnov A.M., Research results obtained in USSR concerning etiology, pathogenesis, epizootiology, diagnosis and control of Varroa disease, Apiacta 13 (1978) 149-162.

[88] Tonelli S., Sostanze naturali antivarroa se usate bene funzionano, Apitalia (1989) 11-12.

[89] Trouiller J., Moosbeckhofer R., Resistenz der Varroa gegen Pyrethroide, Bienenvater 118 (1997) 6-9

[90] Tüshaus M., Gaschromatographischer und sensorischer Thymolnachweis in Bienenhonig zur Beurteilung der Rückstandsproblematik bei der Varroabekämpfung mit ätherischen Ölen, Dissertation, Universität Hohenheim, 1993.

[91] Van der Steen J., Der Effekt einer Mischung ätherischer Oele auf die Varroainfektion in Bienenvölkern, Apidologie 23 (1992) 383

[92] Vandame R., Colin M.E., Belcunces L. P., Jourdan P., Résistance de varroa au fluvalinate, Abeilles et Fleurs (1995) 15-22.

[93] Vecchi M.A., Giordani G., Chemotherapy of acarine disease. I. Laboratory tests, J. Invertebr. Pathol. 10 (1968) 390-416.

[94] Wallner A., Imkern heute - Meine Betriebsweise, die Varroakiller-Biene, Auslesekriterien, Wallner A., Randegg, 1990.

[95] Weiss E.A., Essential Oil Crop, CAB International, Wallingford, UK, 1997.

[96] Wiedmer H., Wirksamkeit von Apistan gegen Varroa in der Schweiz, Schweiz. Bienenztg. 119 (1996) 270. 